\title{
The Probable Pagan Origin of an Ancient Jewish Custom: Purification with Red Heifer's Ashes
}

\author{
Efraim Lev ${ }^{1^{*}}$, Simcha Lev-Yadun ${ }^{2 *}$ \\ ${ }^{1}$ Department of Israel Studies, University of Haifa, Mt. Carmel, Haifa, Israel \\ ${ }^{2}$ Department of Biology \& Environment, Faculty of Natural Sciences, University of Haifa-Oranim, Tivon, Israel \\ Email: elev@univ.haifa.ac.il, levyadun@research.haifa.ac.il
}

How to cite this paper: Lev, E., \& LevYadun, S. (2016). The Probable Pagan Origin of an Ancient Jewish Custom: Purification with Red Heifer's Ashes. Advances in Anthropology, 6, 122-126.

http://dx.doi.org/10.4236/aa.2016.64011

Received: June 27, 2016

Accepted: November 13, 2016

Published: November 16, 2016

Copyright $\odot 2016$ by authors and Scientific Research Publishing Inc. This work is licensed under the Creative Commons Attribution International License (CC BY 4.0). http://creativecommons.org/licenses/by/4.0/

\begin{abstract}
One of the most enigmatic of all ancient Jewish religious customs was the use of ashes of a red heifer to purify people and objects defiled by a corpse. The ashes were combined with spring water and other ingredients in a vessel to produce a mixture called "water of lustration", which was sprinkled on the impure objects or people. We discuss four questions concerning the use of the ashes of the red heifer: (I) Why a cow? (II) Why red? (III) Why ashes? (IV) Was it an original Jewish innovation, or like various other aspects of the Jewish religion, the modification of an earlier pagan rite? We propose that this Jewish rite resembles an ancient Egyptian rite in which red-haired men or cattle were scarified and burnt and their ashes scattered with winnowing fans. We argue that the Jewish red heifer ash ritual may have originated in surrounding pagan cultures reflecting the transition from pantheism to monotheism.
\end{abstract}

\section{Keywords}

Ashes, Jewish Rite, Monotheism, Pagan, Purity, Red Heifer

\section{Introduction}

Three critical cultural developments, all originating in the Near East, underlie Western culture: the invention of agriculture about 10,600 years ago, which made possible the existence of large, structured human populations; the beginning of writing some 6000 years ago, which made possible the accumulation and development of knowledge; and the transition from pantheism to monotheism about 3500 years ago, which advanced the spiritual component of society; that in about 2000 years after the foundation of Judaism replaced pantheism with monotheism in the heart of the Old World. While bo-

${ }^{\star}$ Both authors contributed equally to this paper. 
tany, archaeology and genetics provide good indications of the first two revolutions (Diamond, 1997; Lev-Yadun et al., 2000; Zohary et al., 2012; Salamini et al., 2002), the roots of the spiritual revolution (foundation of monotheism) are still enigmatic. Our hypothesis is intended to illuminate a specific component of this complicated transition.

\section{The Red Heifer Rite}

The rite of the red heifer is ascribed in the Bible to Moses and his brother Aaron, the first high Jewish priest, but the slaughtering and burning of the red-haired animal were first performed by the priest Eleazar (Numbers, 19: pp. 1-22). The Bible teaches us that the red heifer (more properly "red cow", Hebrew parah aduma) must be red or rather reddish-brown in color, without blemish, and have never been yoked. After its slaughter some of its blood was sprinkled seven times toward the front of the Tent of Meeting (the traveling temple). The carcass was then burnt outside the camp. Next, its ashes were then mixed with the ash of cedar wood, crimson stuff and hyssop, all collected by a ritually clean man and placed outside the camp in a ritually pure place. Spring water (Hebrew mayim hayyim) was then added to the mixture in a vessel to produce a solution called "water of lustration" (Hebrew mei niddha). This was sprinkled on the impure objects or people on the third and seventh day after defilement, sustained by touching a corpse, a grave, or a human bone, or by being under the same roof with any of these (Gruber, 1972). The central idea of the red heifer ritual seems to be the efficacy of ashes as a cathartic, due to their connection with fire (Kennedy, 1963). Many related issues regarding the details of the act and the purity of the people involved have been treated since biblical times, mainly in the writings of the Sages (Strikovsky, 1972; Baumgarten, 1993; Milgrom, 1994; Neusner, 1994). Throughout the ages, only seven or nine red heifers were burnt (Browning, 1996).

\section{Types of Ancient Purification Rites}

Was this an original Jewish innovation? Purification of pollution is a major theme in almost all prominent pagan and monotheistic religions, e.g., Hinduism, Christianity, Islam and Judaism, since it forges a path of expiation, healing, renewal, transcendence and reintegration, establishing harmonious links between the individual, the cosmos and the social structure (Ortner, 1993; Preston, 1995). Religious pollution always calls for specific rituals of purification. Common active purification rites can be classified into any of several categories according to the principle on which they operate: (I) removal of pollution, (II) transformation of pollution into purity, (III) destruction of pollution, and (IV) introduction of purity (Ortner, 1993).

The red heifer ritual addressed several of these principles: removal of pollution (washing), transformation into purity (fire), introduction of purity (sprinkling water).

\section{Purification by Cows or Their Products}

Why a cow, and why its ashes? Cows or cattle were sacred in many ancient cultures. In 
India, ash from cow dung is still widely used as a cleansing agent. Since cows are sacred to Hindus, cow dung and other bovine products are considered extremely pure. In India, pollution due to a death (especially when it occurs in a house or temple) is purified by five products of the cow (dung, milk, ghee, curds and urine), which are mixed together and applied as a detergent to clean the walls, or are applied to human beings. In Hinduism the sanctity of the cow, known as the mother of life, makes this mixture almost sacramental in its efficacy. Since fire is regarded by Hindus as highly purifying, cow dung ashes are considered especially pure. Cattle urine was also used for purification by ancient Persians and goes "far back to an Indo-European past" (Modi, 1937; Simoons, 1974).

\section{The Genetic Evidence for Ancient Origin of Cattle}

The origin of domesticated cattle is old, and genetic evidence indicates that its domestication occurred more than once and in several regions (Loftus et al., 1994; Troy et al., 2001; Hanotte et al., 2002). For instance, the origin of most traditional European cattle varieties is Near Eastern (Troy et al., 2001) and African cattle has some Near Eastern genetic components in addition to its indigenous African gene pools (Hanotte et al., 2002). The spread of domesticated cattle over large areas probably resulted in influencing local traditions with specific rites related to cattle. It is possible that some of these rites even predate cattle domestication.

\section{Red Hair and Ancient Middle Eastern Sacrifice}

Why red? The use of red-haired subjects for sacrifice has venerable roots in the Middle East. The ancient Egyptians had a tradition of burning red-haired men and cattle and scattering their ashes with winnowing fans (Frazer, 1990). This sacrifice was offered by the king at the grave of Osiris (Diodorus of Sicily, 1968; Murphy, 1985). As in the Jewish rite, the red-haired oxen that were sacrificed in ancient Egypt also had to be perfectly red (Diodorus of Sicily, 1968): a single black or white hair found on the beast disqualified it for the sacrifice (Herodotus, 1966).

\section{Conclusion}

Was purification with red heifer's ashes an original Jewish innovation or a modification of an earlier pagan rite? Human sacrifice was practiced in many societies and religions in the ancient Near Eastern world. Archaeological and literary evidence has been found, mainly from the irrigation civilizations at both ends of the Fertile Crescent, namely Egypt and the kingdoms of Mesopotamia (Green, 1975), where the documentation is good (Murphy, 1985). These influential societies had various cultural impacts on the smaller nations in the Levant through trade, marriage, and diplomatic affairs, as well as through direct conquest and control (Hallow, 1996). The Canaanite culture that co-occupied the same land as the Israelites regularly practiced child sacrifice (Bergmann, 1992), intimations of which are found even in the Bible (Leviticus, 18: p. 21; Deuteronomy, 18: p. 10; Kings II, 15: p. 3, 17: p. 17, 21: p. 6, 23: p. 10). Jews, howev- 
er, replaced the Canaanite tradition of human sacrifice with animal sacrifice, charity and prayer (Ben Maimon, 1963). It seems likely that the ancient Egyptian ritual that used the ashes of red-haired humans and cattle, and probable similar Levantine rites that were lost, were the origin of the Jewish custom of using the ashes of a red heifer. We argue that the Jewish religion, which was established and accepted by some tribes in the Levant more than 3000 years ago was influenced by the Egyptian culture, especially following the Egyptian rule of the southern Levant in the Late Bronze Age (ca. 1550-1200 B.C.) (Na'aman, 1982). Macalister (Macalister, 1951) proposed that the red heifer ritual is probably very ancient. We propose that the Jewish religion, however, seems to have changed the original pagan ritual involving human sacrifice in certain cases to one that purifies from defilement only with animal sacrifice. The enigmatic origin of this rite (Baumgarten, 1993) no doubt accords with the general lack of detailed knowledge on the transition from a pagan Canaanite tribe into the Israelite nation. The dramatic cultural change from pantheism to monotheism should be studied without religious restrictions in order to understand its roots, probably in the Late Bronze Age of the Near East.

\section{References}

Baumgarten, A. I. (1993). The Paradox of the Red Heifer. Vetus Testamentum, 43, 442-451. https:/doi.org/10.2307/1518494

Ben Maimon, M. (1963). The Guide of the Perplexed (Part III, Chapters 29, 32). Chicago: University of Chicago Press.

Bergmann, M. S. (1992). In the Shadow of Moloch: The Sacrifice of Children and Its Impact on Western Religions. New York: Columbia University Press.

Browning Jr., D. C. (1996). The Strange Search for the Ashes of the Red Heifer. The Biblical Archaeologist, 59, 74-89. https:/doi.org/10.2307/3210511

Deuteronomy, 18, 10.

Diamond, J. (1997). Guns, Germs, and Steel. New York: W.W. Norton \& Company.

Diodorus of Sicily (1968). Diodorus of Sicily in Twelve Volumes (Vol. II, 37-39, p. 321). London: William Heinemann Ltd.; Cambridge: Harvard University Press.

Frazer, J. G. (1990). The Golden Bough (13th ed., part IV, Adonis Attis Osiris). London: Macmillan. https:/doi.org/10.1007/978-1-349-00400-3

Green, A. R. W. (1975). The Role of Human Sacrifice in the Ancient Near East. Missoula: Scholars Press.

Gruber, M. I. (1972). Red Heifer. In Encyclopaedia Judaica (Vol. 14, pp. 9-11). Jerusalem: Keter Publishing House.

Hallow, W. W. (1996). Origins: The Ancient Near Eastern Background of Some Modern Western Institutions. Leiden: Brill.

Hanotte, O., Bradley, D. G., Ochieng, J. W., Verjee, Y., Hill, E. W., \& Rege, J. E. O. (2002). African Pastoralism: Genetic Imprints of Origins and Migrations. Science, 296, 336-339.

https:/doi.org/10.1126/science.1069878

Herodotus (1960). Herodotus. With an English Translation by A. D. Godley(Book II. 38, Vol. 1, p. 321). Cambridge: Harvard University Press.

Kennedy, A. R. S. (1963). Red Heifer. In F. C. Grant, H. H. Rowley, \& J. Hastings (Eds.), Dictio- 
nary of the Bible (2nd Revised Ed., pp. 835-836). New York: Charles Scribner's Sons.

Kings, II, 15, p. 3; 17, p. 17; 21, p. 6; 23, p. 10.

Lev-Yadun, S., Gopher, A., \& Abbo, S. (2000). The Cradle of Agriculture. Science, 288, 16021603. https:/doi.org/10.1126/science.288.5471.1602

Leviticus, 18, p. 21.

Loftus, R. T., MacHugh, D. E., Bradley, D. G., Sharp, P. M., \& Cunningham, P. (1994). Evidence for Two Independent Domestications of Cattle. Proceedings of the National Academy of Sciences of the United States of America, 91, 2757-2761. https:/doi.org/10.1073/pnas.91.7.2757

Macalister, R. A. S. (1951). Sacrifice. In J. Hastings (Ed.), Encyclopaedia of Religion and Ethics (Vol. 14, pp. 31-38). New York: Charles Scribner's Sons.

Milgrom, J. (1994). Confusing the Sacred and the Impure: A Rejoinder. Vetus Testamentum, 44, 554-559. https:/doi.org/10.1163/156853394X00547

Modi, J. J. (1937). The Religious Ceremonies and Customs of the Parsees (2nd ed.). Bombay: Jehangir B. Karani's Sons.

Murphy, E. (1985). Diodorus Siculus: Diodorus on Egypt (pp. 113-115). London: McFarland \& Company Inc.

Na'aman, N. (1982). Palestine in the Canaanite Periods: The Middle and Late Bronze Age. In I. Efal (Ed.), The History of Eretz-Israel (Vol. 1, pp. 131-275). Jerusalem: Keter. (In Hebrew)

Neusner, J. (1994). Purity in Rabbinic Judaism: A Systematic Account: The Sources, Media, Effects, and Removal of Uncleanness. Studies in the History of Judaism, No. 95, Atlanta: Scholars Press.

Numbers, 19, pp. 1-22.

Ortner, S. B. (1993). Purification Rites and Customs. In The New Encyclopaedia Britannica (Vol. 26, pp. 810-815). Chicago.

Preston, J. (1995). Purification. In M. Elidae (Ed.), The Encyclopedia of Religion (Vol. 11, pp. 91-100). New York: Macmillan.

Salamini, F., Özkan, H., Brandolini, A., Schäfer-Pregl, R., \& Martin, W. (2002). Genetics and Geography of Wild Cereal Domestication in the Near East. Nature Reviews Genetics, 3, 429441.

Simoons, F. J. (1974). The Purificatory Role of the Five Products of the Cow in Hinduism. Ecology of Food and Nutrition, 3, 21-34. https:/doi.org/10.1080/03670244.1974.9990358

Strikovsky, A. (1972). Red Heifer, in the Talmud. In Encyclopaedia Judaica (Vol. 14, pp. 11-13). Jerusalem.

Troy, C. S., MacHugh, D. E., Balley, J. F., Magee, D. A., Loftus, R. T., Cunningham, P., Chamberiain, A. T., Sykes, B. C., \& Bradley, D. G. (2001). Genetic Evidence for Near Eastern Origins of European Cattle. Nature, 410, 1088-1091. https:/doi.org/10.1038/35074088

Zohary, D., Hopf, M., \& Weiss, E. (2012). Domestication of Plants in the Old World: The Origin and Spread of Domesticated Plants in Southwest Asia, Europe, and the Mediterranean Basin (4th ed.). Oxford: Oxford University Press.

https:/doi.org/10.1093/acprof:osobl/9780199549061.001.0001 